\title{
Importance of Dietary Therapy (Ilaj Bil Ghiza) in Unani System of Medicine
}

\section{Usama Akram* and N Quddusi}

Research Officer (Unani), Central Council for Research in Unani Medicine, Ministry of AYUSH, Government of India, India

*Corresponding Author: Usama Akram, Research Officer (Unani), Central Council for Research in Unani Medicine, Ministry of AYUSH, Government of India, India.

DOI: 10.31080/ASNH.2020.04.0631
Received: January 17, 2020

Published: January 31, 2020

(C) All rights are reserved by Usama Akram and N Quddusi.

\begin{abstract}
Today's major health care problems are increasingly the result of acute and chronic conditions related to poor nutrition and/ or overconsumption. A large proportion of coronary disease and cancer can be attributed to unhealthy eating habits and obesity. Chronic diseases continue to increase due to such factors as the rise in obesity in the global population.

Individualized diet therapy can provide the patient important insight into food-related illnesses and education regarding how various nutrients (protein, carbohydrate, fat, alcohol) affect illness, diseases, or obesity. Dietary therapy (Ilaj bil Ghiza) can be tailored to meet the treatment needs of patients on diagnosis of specific illnesses, can help reduce complications and/or side effects, and can improve general well-being.

The Unani system of medicine believes that a physician is not the healer but an assistant to nature Tabiyat (physique) of the body, which is the true healer hence the diet should be in accordance with it. Diets have been mentioned according to various stages of life to maintain the digestive system at its best. Unani dietary therapy deals with certain ailments by treating them with specific diets or by regulating the quantity and quality of food.

Ibn-e-Sina (Avicenna) wrote, "Most illnesses arise solely from long-continued errors of diet and regimen." The manner in which foods affect the body is viewed in Unani from a simple yet highly interesting viewpoint.

In this paper efforts have been made to elaborate the concept of Dietary Therapy (Ilaj bil Ghiza) in Unani system of medicine as well as its importance, classifications, terms and benefits.

Keywords: Unani; Ilaj Bil Ghiza; Dietary Therapy; Tabiyat; Ibn-e-Sina
\end{abstract}

\section{Introduction}

The term diet is derived from Greek word 'diaita' means a way of living. It is defined as liquid and solid food substances regularly consumed in the course of normal living or a prescribed allowance of food adapted for a particular state of health or disease [1]

Dietary therapy is the application of foods for the purpose of preservation of strength, flesh and energy or to their repair when diminished by disease. Necessarily the value of foods in health must be understood in order to appreciate their relative utility in disease. The human body contains the following chemical elements: Carbon, hydrogen, oxygen, nitrogen, sulphur, phosphorus, chlorine, iodine, potassium, sodium, calcium, magnesium and iron. A few other elements have been found in the human body, but they are not uniformly present. It is self-evident that food that is to make an infant's body grow to man's dimensions and capacity must contain these elements. It is, however, impossible to feed human beings upon chemical elements. To become useful they must be furnished in certain combinations [2].

On the other hand, Dietary Therapy is a therapy by which patients are treated with a non medicinal therapy from which health is attained by modulation of dietary habits [3]. In modern era, $\mathrm{Nu}$ trition is educated as a separate kind of science which deals with science of food, the nutrient and the other substances, their action, interaction and balance in relation to health and disease and the processes by which the organism ingests, digests, absorbs, transports, utilizes and excrete food substances [4].

\section{Historical Background}

Dietary Therapy has an old history, it stems from the Zhou Dynasty, 1000 BC. Zhang Ji, a distinguished physician in the Han Dynasty realized the action of dietary therapy during the rehabilitation from disease [5]. Egyptian, Roman, Greeks such as Hippocrates (460-327 BC), Aristotle (384-377BC), Celus (53BC-7AD), Galen (130-200AD) were great legends in dietetics. They gave much importance to diet during health and sickness [6]. In Unani system of medicine, the role of diets and drinks for health issues has been considered very much significant since date back. Hippocrates has compiled two treatises on dietary therapy as 'Kitab al-Ghiza' (book on dietetics) and 'Kitab Ma-us-Shaeer' (book on barley water). Aristotle, Celus and Galen have also emphasized on the use of various food items for the treatment of common and specific diseases of the human body. Aristotle wrote the book 'Kitab fi Tadbeer al- Agh- 
zia' (book on diet management). Galen compiled the book 'Kitab Qawi al-Aghzia' (book on the strength of diets). Masar Joya Basri (d. 730 AD) compiled 'Kitab al-Aghzia' (book on diets). Jibreel ibn Bakhteeshu (d. 828 AD) wrote 'Risala fi al-Taamva al-Sharab' (document on food and drink). Ibn Masoya (d. 857 AD) wrote number of books on various aspects of nutrition and dietary therapy e.g. 'Kitab fi al-Ashrab' (book on drinks), 'Kitab fi al-Aghzia' (book on diets), 'KitabKhawas al-Aghziawa al-Buqul' (book on the properties of diets and vegetables), Kitab fi Sharab al-Fakeh' (book on drink and fruits). HunyenIbnIshaq (d. 873 AD) has compiled three books on diet i.e. 'Kitab fi-l-Labn' (book on milk), 'KitabQawi alAghzia' (book on strength of diets) and 'Kitab fi Tabae al-AghziawaTadbeer al-Insan' (book on nature of diet and management). The 'KitabJalinus fi al-Aghzia' (book of Galen on diets) is compiled by Sabitibn Qartah (d. 901 AD). Qusta bin Luqa (d. 912 AD) has written 'Kitab al-Aghzia ala Tareeq Qawaneen al-Qulliya'(book on dietary principles). Razi (d. 925AD) has written two manuscripts on dietetics i.e. 'Kafiyat al-Aghtiza' and 'Kitab Munafe al-Aghziava Dafe Mazariha'. Ibn Butlan (d. 1064 AD) has compiled 'Taqveem al-Sahet fi Quwa al-Aghzia va Dafe Mazariha'. Najeebuddin Samarqandi (d. 1220 AD) wrote 'Risale Aghziawa-l-Ashrab alil Marza' [7].

According to Ibne-Sina, Abu-Sahal Masihi and Rabban Tabri, there are four types of naturally occurring edible items i.e. Ghiza (food), Dawa (drug), Ghiza-e-Dawai (food n drug) and Dawa-eGhizai (drug n food). Ghiza and Ghiza-e-Dawai comprise cereals, pulses, fruits, vegetables, eggs, meat, sugar, honey, etc. whereas, Dawa and Dawa-e-Ghizai comprise different plant parts, herboanimo-mineral items, horns, teeth, castoreum, liver, brain, fat, blood, glands and birds and Zavi-al-ajsad (gold, zinc, silver, copper, iron), Zavi-al-arwah (sulphur, mercury, arsenic), Hajaryat (diamond, jad, sapphire) and Araziat (gil-e-makhtoom, gil-e-armani, gil-e-multani) from mineral origin. Ghiza and Ghiza-e-Dawai are used to maintain physical and mental health, and Dawa and Dawae-Ghizai are used to eradicate the disease not only by providing nutrition but also by combating the disorder either by their action on the micro-somal-enzyme systems of the body or on microorganism directly. Basically, Ghiza-e-Dawai and Ghiza energize and nourish the body and ultimately escalate the body resistance to prevent from diseases [3].

\section{Concept of diet in unani medicine}

According to Unani physicians it is believed that diet/food provides strength to the body and to the morbid matters both. The wrong selection and misappropriation of diet may hamper the tabiyat (physic) which is known to increase the severity of diseases. Complete restriction from diet or partially reduction is generally advised in acute diseases whereas only partial reduction is recommended in chronic diseases so that the faculties of the body may be restored.

- Tark-e-Ghiza (Stop diet): When the tabiyat (physic) is strong, such patients are advised to stop the diet completely; which helps in evacuation of morbid matter from the body.
- Taqleel-e-Ghiza (Reduced diet intake): The amount of food is reduced quantitatively as well as qualitatively with an aim to restore quwa (faculties of the body), which helps tabiyat (physic) to work solely in one direction and participate in eradication of disease from the body. Half boiled egg may be advised if quwa (faculty) of the body is weak. On the other hand, watermelon and muskmelon can be advised if quwa (faculty) of the body is strong.

The diet can be reduced as per the following details:

- Reduction in kammiyat (quantity) of the diet: The quantity of diet is reduced but the nutritional value does not get affected. This type of diet is advised when digestion of the patient is weak but needs to provide strength to the faculties of the body e.g. egg.

- $\quad$ Reduction in kaifiyat (quality) of the diet: The quantity of diet in terms of nutritional value is reduced. This type of diet is advised when the patient has desire of food but simultaneously the vascular system of the body is hampered with morbid matters. In this situation, the production of humours is decreased which provides favourable medium for concoctive action of morbid matters e.g. vegetables and fruits.

- $\quad$ Reduction in kammiyat (quantity) and kaifiyat (quality) of the diet: The diet in terms of quantity and quality both, is reduced particularly when faculties of the body are not markedly disturbed [7].

Dietary terms used in Unani medicine $[7,8]$.

\begin{tabular}{|l|l|}
\hline Terms & Description \\
\hline $\begin{array}{l}\text { Ghiza-e-Lateef } \\
\text { (Light and soft diet) }\end{array}$ & $\begin{array}{l}\text { The foods which are easily digested } \\
\text { and reduce the viscosity of khilt (hu- } \\
\text { mour) inside body. e.g. Aab-e-anar } \\
\text { (pomegranate juice), Aab-e-mosambi } \\
\text { (orange-navel juice), Aab-e-naranji } \\
\text { (orange juice), Ma-al-shaeer (barley } \\
\text { water), tea, coffee, wine, etc. }\end{array}$ \\
\hline $\begin{array}{l}\text { Ghiza-e-Lateef Kasser-ut- } \\
\text { Taghzia (Attenuated highly } \\
\text { nutritious diet) }\end{array}$ & $\begin{array}{l}\text { The foods which are easily digested } \\
\text { and rich in calories such as Ma-al- } \\
\text { lahem (meat distillate) and Zardi } \\
\text { baiz-e-murg neem birasht (yolk of } \\
\text { half boiled egg). }\end{array}$ \\
\hline $\begin{array}{l}\text { Ghiza-e-Lateef Qaleel-ut- } \\
\text { Taghzia (Attenuated less } \\
\text { nutritious diet) }\end{array}$ & $\begin{array}{l}\text { The foods which are digested easily } \\
\text { and having low calories such as } \\
\text { fruits. }\end{array}$ \\
\hline $\begin{array}{l}\text { Ghiza-e-Lateef Kasser-ut- } \\
\text { Taghzia jayyad al-Kaimus } \\
\text { (Attenuated, highly nutri- } \\
\text { tious and good chyme form- } \\
\text { ing diet) }\end{array}$ & $\begin{array}{l}\text { The foods which are digested easily, } \\
\text { having high calories and produce } \\
\text { good chyme such as meat distillate, } \\
\text { yolk of half boiled egg etc. }\end{array}$ \\
\hline $\begin{array}{l}\text { Ghiza-e-Lateef Kasser-ut- } \\
\text { Taghzia raddi al-Kaimus } \\
\text { (Attenuated, highly nutri- } \\
\text { tious and bad chyme form- } \\
\text { ing diet) }\end{array}$ & $\begin{array}{l}\text { The foods which are digested easily, } \\
\text { having high calories and produce } \\
\text { bad chyme such as liver and lung. }\end{array}$ \\
\hline $\begin{array}{l}\text { Ghiza-e-Lateef Qaleel-ut- } \\
\text { (Attenuated, less nutritious } \\
\text { diet) }\end{array}$ & $\begin{array}{l}\text { The foods which are digested easily, } \\
\text { having low calories and produce } \\
\text { good chyme such as fruit juices and } \\
\text { fruits. }\end{array}$ \\
\hline
\end{tabular}




\begin{tabular}{|c|c|c|c|}
\hline \multirow{2}{*}{$\begin{array}{l}\text { Ghiza-e-Lateef Qaleel-ut- } \\
\text { Taghzia raddi al-Kaimus } \\
\text { (Attenuated, less nutri- } \\
\text { tious and bad chyme } \\
\text { forming diet) }\end{array}$} & \multirow{2}{*}{$\begin{array}{l}\text { The foods which are digested } \\
\text { easily, provide less energy and } \\
\text { produce bad chime e.g. radish, } \\
\text { mustard, lettuce, etc. }\end{array}$} & Aghziya Mubakhkhira & $\begin{array}{l}\text { The food liable to produce flatus } \\
\text { and vapours e.g. cabbage, pea, brin- } \\
\text { jal, cauliflower, beans, turnip, etc. }\end{array}$ \\
\hline & & Aghziya Mughalliz-e-Dam & $\begin{array}{l}\text { Foods producing Dam (Sanguine) } \\
\text { of thick consistency. }\end{array}$ \\
\hline \multirow{2}{*}{$\begin{array}{l}\text { Ghiza-e-Kaseef (Heavy } \\
\text { diet) }\end{array}$} & \multirow{2}{*}{$\begin{array}{l}\text { The foods which are not digested } \\
\text { easily, form ghaleez khilt (viscous } \\
\text { humour) which produces sudda } \\
\text { (obstruction) in organs. }\end{array}$} & Aghziya Mugharriya & Glutinous foods. \\
\hline & & Aghziya Mujaffifa & $\begin{array}{l}\text { Foods causing desiccation of body } \\
\text { fluid e. g. roasted gram. }\end{array}$ \\
\hline \multirow{2}{*}{$\begin{array}{l}\text { Ghiza-e-Kaseef Kasser-ut- } \\
\text { Taghzia (Heavy and highly } \\
\text { nutritious diet) }\end{array}$} & \multirow{2}{*}{$\begin{array}{l}\text { The foods which are not digested } \\
\text { easily and having high calories } \\
\text { such as beef. }\end{array}$} & Aghziya Muraqqiq-e-Dam & $\begin{array}{l}\text { Foods that cause thinning of Dam } \\
\text { (Sanguine) }\end{array}$ \\
\hline & & \multirow{3}{*}{$\begin{array}{l}\text { Aghziya Murattiba / } \\
\text { Aghziya Rataba }\end{array}$} & \multirow{3}{*}{$\begin{array}{l}\text { Foods of wet /moist tempera- } \\
\text { ment having ability to produce } \\
\text { the humours which give rise to } \\
\text { wetness in the body e.g. milk, kadu, } \\
\text { (Cucurbita maxima Duchesne.) } \\
\text { cucumber, watermelon, clarified } \\
\text { butter, almond oil, etc. }\end{array}$} \\
\hline $\begin{array}{l}\text { Ghiza-e-Kaseef Qalil-ul- } \\
\text { Taghzia (Heavy and less } \\
\text { nutritious diet) }\end{array}$ & $\begin{array}{l}\text { The foods which are not digested } \\
\text { easily and having high calories } \\
\text { such as dry beef. }\end{array}$ & & \\
\hline \multirow{2}{*}{$\begin{array}{l}\text { Ghiza-e-Kaseef Kasser-ut- } \\
\text { Taghzia jayyad al-Kaimus } \\
\text { (Heavy, highly nutritious } \\
\text { and good chyme forming } \\
\text { diet) }\end{array}$} & \multirow{2}{*}{$\begin{array}{l}\text { Heavy and highly nutritious foods } \\
\text { which produce good chmye e.g. } \\
\text { fully boiled egg, meat of young } \\
\text { sheep, etc. }\end{array}$} & & \\
\hline & & Aghziya Musakhkhina & $\begin{array}{l}\text { Foods producing heat in the body } \\
\text { e.g. spices. }\end{array}$ \\
\hline \multirow{3}{*}{$\begin{array}{l}\text { Ghiza-e-Kaseef Kasser-ut- } \\
\text { Taghzia raddi al-Kaimus } \\
\text { (Heavy, highly nutritious } \\
\text { and bad chyme forming } \\
\text { diet) }\end{array}$} & \multirow{3}{*}{$\begin{array}{l}\text { The foods which are not digested } \\
\text { easily and always produce bad } \\
\text { chmye e.g. duck meat and horse } \\
\text { meat. }\end{array}$} & Aghziya Musammina & $\begin{array}{l}\text { The foods which help to put on } \\
\text { body weight e.g. dry fruits, milk } \\
\text { and products, etc. }\end{array}$ \\
\hline & & Aghziya Mutaaffina & Putrefied food stuffs. \\
\hline & & Aghziya Muwallid-e- & The foods which produce excessive \\
\hline \multirow{2}{*}{$\begin{array}{l}\text { Ghiza-e-Kaseef Qaleel-ul- } \\
\text { Taghzia jayyad al-Kaimus } \\
\text { (Heavy, less nutritious } \\
\text { and good chyme forming } \\
\text { diet) }\end{array}$} & \multirow[t]{2}{*}{$\begin{array}{l}\text { Less nutritious foods which } \\
\text { produce good chmye e.g. meat of } \\
\text { young beef. }\end{array}$} & Balgham & $\begin{array}{l}\text { quantity of phlegm in the body e.g. } \\
\text { sheep milk, beet root, cucumber, } \\
\text { etc. }\end{array}$ \\
\hline & & Aghziya Muwallid-e-Dam & $\begin{array}{l}\text { The foods which produce an exces- } \\
\text { sive quantity of sanguine in the }\end{array}$ \\
\hline \multirow{2}{*}{$\begin{array}{l}\text { Ghiza-e-Kaseef Qaleel-ul- } \\
\text { Taghzia raddi al-Kaimus } \\
\text { (Heavy, less nutritious } \\
\text { and bad chyme forming } \\
\text { diet) }\end{array}$} & \multirow[t]{2}{*}{$\begin{array}{l}\text { Less nutritious and heavy foods } \\
\text { which are not digested easily and } \\
\text { produce bad chmye e.g. dry beef } \\
\text { meat. }\end{array}$} & & $\begin{array}{l}\text { body e.g. grapes, pomegranate, egg } \\
\text { yolk, fried meat, boiled meat, milk, } \\
\text { dairy products, gram, etc. }\end{array}$ \\
\hline & & Aghziya Muwallid-e-Safra & $\begin{array}{l}\text { The foods which produce an exces- } \\
\text { sive quantity of vellow bile in the }\end{array}$ \\
\hline \multirow{2}{*}{$\begin{array}{l}\text { Ghiza-e-Motadil (Moder- } \\
\text { ate diet) }\end{array}$} & \multirow{2}{*}{$\begin{array}{l}\text { Foods that produce khilt (humour) } \\
\text { of moderate viscosity which is not } \\
\text { harmful to the human body e.g. } \\
\text { Khichdi, cow's milk, etc. }\end{array}$} & & body e.g. cheese. \\
\hline & & $\begin{array}{l}\text { Aghziya Muwallid-e- } \\
\text { Sawda }\end{array}$ & $\begin{array}{l}\text { The foods which produce an exces- } \\
\text { sive quantity of black bile in the } \\
\text { body e.g. buffalo meat, cabbage. }\end{array}$ \\
\hline \multirow{3}{*}{$\begin{array}{l}\text { Aghzia Barida/Aghziya } \\
\text { Mubarrida }\end{array}$} & \multirow{3}{*}{$\begin{array}{l}\text { The food of cold temperament hav- } \\
\text { ing ability to produce the humours } \\
\text { which induce coldness in the body } \\
\text { e.g. Khas (Andropogan muricatus } \\
\text { Retz.), Kasni (Cichorium intybus } \\
\text { Linn.), etc. }\end{array}$} & & brinjal, etc. \\
\hline & & Aghziya Nashifa & $\begin{array}{l}\text { Foods that have the property of } \\
\text { absorbing the moisture of the body. }\end{array}$ \\
\hline & & Aghziya Radiyya & $\begin{array}{l}\text { Foods that produce bad quality of } \\
\text { humours. }\end{array}$ \\
\hline \multirow[t]{2}{*}{ Aghziya Hamiza } & \multirow{2}{*}{$\begin{array}{l}\text { Sour foods e.g. lemon, sour } \\
\text { pomegranate, sour apple, orange, } \\
\text { vinegar, curd, etc. They change the } \\
\text { thick waste products of stomach } \\
\text { into smaller particles. }\end{array}$} & Aghziya Saliha & $\begin{array}{l}\text { The foods which produce good } \\
\text { quality of humours. }\end{array}$ \\
\hline & & Aghziya Saqila & $\begin{array}{l}\text { The foods which are difficult to } \\
\text { digest. }\end{array}$ \\
\hline Aghziya Harra & $\begin{array}{l}\text { The foods of hot temperament hav- } \\
\text { ing ability to produce the humours }\end{array}$ & Aghziya Yabisa & $\begin{array}{l}\text { The foods of dry temperament } \\
\text { which produce dryness in the body } \\
\text { e.g. meat, lentil, etc. }\end{array}$ \\
\hline
\end{tabular}

\section{Table 1}

\begin{tabular}{|l|l|}
\hline Aghziya Hirrifa & $\begin{array}{l}\text { Spicy (pungent) foods that may } \\
\text { produce heat in the body e.g. pep- } \\
\text { per. }\end{array}$ \\
\hline Aghziya Lazija & $\begin{array}{l}\text { The foods which increase the } \\
\text { viscosity of humours e.g. Khurfa, } \\
\text { Till, etc. }\end{array}$ \\
\hline Aghziya Mahmuda & Foods that produce good humours. \\
\hline Aghziya Maliha & Salty foods. \\
\hline
\end{tabular}

\section{Specific diets and their uses [6]}

According to Unani system of medicine, many modified diets, separately or as an adjuvant with pharmacotherapy, are also used for the treatment of various diseases. These diets have been mentioned in several Unani pharmacopoea 
- Ma-al-shaeer (Barley water): Barley is soaked in water for four hours, and boiled (in twenty times water) till the colour of water becomes reddish. According to Buqrat (Hippocrates) barley water is most appropriate diet in diseases of hot temperament according to him it eliminates the morbid matter, cleans the system, easily absorbable, palatable, moderate, quenches thirst and easy digestible. It is also useful in acute conditions, cool and moist in nature, moderate, cleanses the system and produces good chyme.

- Jubn (Milk): Itis moderate in temperament with little influence of cold and moist. It possesses three major qualities viz it is light, excess water content helps to eliminate morbid matter, maintains body heat, nourishes and energizes body increases body weight. Milk is useful in those conditions which produce dryness in the body.

- Ma-al-jubn (Milk water): This is prepared by boiling sheep/ goat's milk with equal quantity of water with adding some sour juice like grape or lemon juice to curdle the milk. Then it is filtered through a thick cloth and hanged for some time. Finally water is collected, boiled, filtered, cooled and mixed with sikanjabeen. It works as purgative and used in bilious condition like jaundice. It is dilute and light, easily absorbable and digestible. Its oily contents keep the organs soft that prevents irritation.

- Ma-al-lahm (Meat distillate): It is prepared by process of distillation. This is rich in calories and easy digested. It is used in malnourished and weak patients.

- Ma-al-raib (Butter milk): It is cold and moist in temperament, easy absorbed, cool and quenches thirst.

- Ma-al-asl (Honey water): Honey is boiled with water or herbal decoction. It is useful in fever, irritation, thirst and in dry cough.

- Ma-al-usool: Certain roots like beekhbadyan, kasni, karafs, etc. are crushed and boiled.

- Ma-al-fawakeh (fruit juices).

- Ma-al-buqool: It is extracted juice of crushed, pounded and vegetables.

- Paneer maaya: Itis sort of milk collected after the birth. It is boiled and when cooled it solidifies mostly prepared from milk of camel, cow and sheep. It is nutritious, strengthens heart, brain and useful in diarrhoea.

- Jullab: It is prepared by boiling honey/sugar syrup and rose water. It is used as strong purgative.

- Sikanjabeen (Oxymel): It is prepared by boiling 1 part vinegar and 2 parts honey. It is useful in purging out thickchime. It is a soothing medicine, removes yellow bile, acts as emetic when used with hot water and anti emetic if used with cold water.
- Aabkama (Mar/sirkahindi/Kaanji): Itis prepared by fermentation of mustard, salt, zeera, ajwain or wheat roti, vinegar, salt, mint, ginger, pepper, etc.

- Asfeedaj. It is mutton soup prepared without spices and mostly used in winter season. It is nutritious and energetic.

- Sikbaj. It is prepared with meat and vinegar. It is cool in temperament, anti-bilious and used in inflammation of liver.

- Khamar (Sharab): It is obtained by fermenting starchy substances. It is cardiac, brain stimulant and tonic if used in less quantity but becomes dangerous and toxic when used in large quantity.

- Murabba: Seasonal fruits are preserved by boiling in sugar syrup or honey so that they can be used later. Use of Murabba amla, halela, bihi, adrak, Aam, Seb, etc, strengthens stomach and acts as anti bilious.

- Gulqand: Rose petals are preserved in sugar syrup or honey to form a jam. It is anti-pyretic, moderate laxative, hepatic and cardiac tonic and acts as purgative when used in large quantity.

- Halwa: Maida, Sooji, honey, clarified butter and dry fruits, are mixed in herbs like aloe vera, carrot, onion and prepared as halwa. It is rich in calories, nutritious and energetic preparation.

- Hareesa: A sort of diet prepared by boiling meat and wheat It is pounded into paste and spices are added for flavour.

- Hasarmiya: A diet prepared with grape juice, lauki, palak and cucumber. It is useful in diseases of hot climate and hot temperament and also used as ant bilious.

- Zeerbaaj: Type of soup which is prepared with vinegar, dry fruits, saffron, and spices. It is useful in the diseases of stomach and liver.

- Mazeera. A diet which is prepared with curdled milk. It is cool and viscous and useful in hottemperament.

- Masleeya: This is curd and rice used same as mazeera.

Falooda: A nutritious diet which is prepared with starch, milk or water. It sets when cooled and can be cutinto pieces. It is coolant and nutritious.

- Alqabees: A sort of halwa which is prepared with milk cream, maida and dates similar to falooda.

- Firni: It is prepared with broken rice, sugar and milk. It is nutritious diet.

- Maibah: It is prepared with quince fruit juice, grape wine, honey, powder of dried ginger, cardamom, cinnamon and saffron is added. It strengthens the stomach and useful in diarrhoea, indigestion nausea and vomiting.

- Fateer: It is special type of Rotis which is prepared with fermented or unfermented dough. It strengthens the body. 
- Qashkar: It is kind of Roti which is prepared without removing husk. It is nutritious.

- Hareera: It is prepared with heating of Maida, clarified butter, milk, sugar and dry fruits. It is easily digested coolant, nutritious and used in acute conditions.

Diseases and recommended Unani diets [7]

\begin{tabular}{|c|c|}
\hline Diseases & Recommended Unani diets \\
\hline Headache & $\begin{array}{l}\text { Masoor dal (Red lentil) along with vinegar, } \\
\text { green leafy vegetables, fresh fruits. }\end{array}$ \\
\hline Meningitis & Barley water. \\
\hline $\begin{array}{l}\text { Cerebro-vascular } \\
\text { accident }\end{array}$ & Fresh fruits having cold temperament, ma-al-asl \\
\hline Paralysis & Bengal gram, olive oil, ma-al-asl \\
\hline $\begin{array}{l}\text { Febrile } \\
\text { convulsion }\end{array}$ & Barley water, chicken soup \\
\hline Epilepsy & $\begin{array}{l}\text { Fried mutton, Onion, garlic, Brassica nigra, Vicia } \\
\text { faba, Cabbage }\end{array}$ \\
\hline Melancholia & $\begin{array}{l}\text { Mutton of young sheep, Chicken, Bread of fine } \\
\text { wheat, Fresh milk, Live fish, Sweat made with } \\
\text { Sugar and Roghan-e-Badam. Ma-al-Jubn. Avoid } \\
\text { taking dry mutton, Masoor dal, Cabbage, Salty } \\
\text { and acrid taste food }\end{array}$ \\
\hline Common cold & Barley water, Murabba-e-banafsha \\
\hline Conjunctivitis & Fruit juices \\
\hline Cough & $\begin{array}{l}\text { Barley water, Made vegetable of Vicia faba or } \\
\text { spinach made along with almond oil }\end{array}$ \\
\hline Pleurisy & Barley water \\
\hline Tuberculosis & $\begin{array}{l}\text { Goat's milk, Barley water, Fried fish, Vegetables } \\
\text { made with leaves of Portulaca oleracea, Tribu- } \\
\text { lus terrestris, Lagenaria siceraria and cucumber, } \\
\text { Ma-aul-lahem, Water melon, Pomegranate, } \\
\text { Grape, Prunus domestica, Apple, Turmeric, } \\
\text { Turnip, Ma-al-asl }\end{array}$ \\
\hline Palpitation & $\begin{array}{l}\text { Chicken soup made with mixture of hot spices } \\
\text { and unripe grapes, Sikanjabeen-e-shakri, mu- } \\
\text { rabba-e-amla, Arq-e-kewda, Arq-e-gaozaban, } \\
\text { Murabba-e-anannas, Murabba-e-tamarhindi }\end{array}$ \\
\hline Cholera & $\begin{array}{l}\text { Pomegranate juice alone or mixed with wheat } \\
\text { bread }\end{array}$ \\
\hline Gastritis & $\begin{array}{l}\text { Pomegranate juice, Sikanjabeen, Cydonia } \\
\text { oblonga mixed with wheat bread, Fruits having } \\
\text { cold temperament }\end{array}$ \\
\hline Jaundice & $\begin{array}{l}\text { Vegetable made with pumpkin, Spinach, Malva } \\
\text { sylvestris, Cucumber, Prunus domestica, Solanum } \\
\text { nigrum, Cichorium intybus, Pomegranate juice }\end{array}$ \\
\hline Urolithiasis & Bengal gram, milk, cheese \\
\hline $\begin{array}{l}\text { Burning } \\
\text { micturition }\end{array}$ & Hasramiya \\
\hline $\begin{array}{l}\text { Worm } \\
\text { infestation }\end{array}$ & Wheat bread with Kanji \\
\hline Fever & $\begin{array}{l}\text { Vegetables having cold and moist temperament, } \\
\text { Mutton of young goat, Chicken and live fish, } \\
\text { Diet made with Vinegar, Olive oil and sugar, } \\
\text { Vinegar and almond oil }\end{array}$ \\
\hline
\end{tabular}

\begin{tabular}{|c|c|}
\hline Anorexia & $\begin{array}{l}\text { Fried chick with pomegranate juice and mint, } \\
\text { Live fish, Vinegar, and Onion with vinegar, Fried } \\
\text { chick with Ruta graveolens, Anethum graveo- } \\
\text { lens, Garlic and onion }\end{array}$ \\
\hline Hepatic pain & $\begin{array}{l}\text { Watermelon with sugar, Pumpkin and grape } \\
\text { juice, Cucumber juice along with Solanum } \\
\text { nigrum, Cichorium intybus juices, Portulaca } \\
\text { oleracea, Sikanjabeen and amaltas (cassia fis- } \\
\text { tula). Vegetables such as spinach, Chenopodium } \\
\text { album, leaves of beet root, Portulaca oleracea } \\
\text { leaves with almond oil }\end{array}$ \\
\hline Haematuria & Faluda with almond oil, Rice soup \\
\hline Gout & Prunus domestica, Sugarcane juice \\
\hline $\begin{array}{l}\text { Oligozoospermia } \\
\text { and spermator- } \\
\text { rhoea }\end{array}$ & $\begin{array}{l}\text { Onion, Carrot, Gram, Mint, Fenugreek, Almond, } \\
\text { Walnut, Pistachio nut, Grape, fig, Banana, Dates, } \\
\text { Milk, Egg, Mutton, Chicken, Sweet made with } \\
\text { chest nut, Coconut }\end{array}$ \\
\hline Urticaria & Pomegranate juice, Curd and vinegar \\
\hline Eczema & $\begin{array}{l}\text { Barley water, Cucumber juice, Pumpkin juice, } \\
\text { Mucilage of isabgol }\end{array}$ \\
\hline Diabetes & $\begin{array}{l}\text { Pomegranate juice, Mucilage of isabgol, Prunus } \\
\text { domestica juice, Barley water, Spinach, Pumpkin }\end{array}$ \\
\hline Psoriasis & $\begin{array}{l}\text { Black gram, Pumpkin, Spinach, Fresh milk, } \\
\text { Ma-al-jubn, Fresh milk along with Black gram } \\
\text { and Almond. Cold dry, hard and melancholic } \\
\text { producing diets like Red meat, Salty fish and } \\
\text { cheese should be avoided }\end{array}$ \\
\hline Obesity & $\begin{array}{l}\text { Onion, Garlic, Mint, Carum carvi, Piper longum, } \\
\text { Green leafy vegetables }\end{array}$ \\
\hline
\end{tabular}

Table 2

\section{Conclusion}

This may be concluded that the Unani medicine has given a clear guidance on description, classification and role of diet which could be enlighten the modern terms Dietary therapy for the better utilization in both health and disease of a person.

\section{Bibliography}

1. Venes D. Taber's Encyclopedic Medical Dictionary. 21st ed. USA. America: FA Davis Company Philadelphia (2009): 644649.

2. Davis. Dietotherapy and Food in Health; P. Blakiston's Son and Co. Philadelphia (1909): 17-18.

3. Hamdani SM, Kamaluddin Hussain, Ussole Tib and Ali Manzil. Muslim, University, Aligarh. (1980): 425-428,39,406,214.

4. Wiiliams SR. Basic Nutrition and Diet therapy, 10th ed. MosbyYear book, Inc. USA. (1995): 5.

5. Boping Wu. Chinese Medicated Diet a Historical Prospective 3 (2005).

6. Roohi Zaman., et al. "Dieto Therapy in Unani System of Medicine". IJPCBS 3.4 (2013): 1035-1039. 
7. Ansari AP., et al. "Ilaj bil Ghiza (Dietotherapy): A Core Mode of Unani Treatment". Journal of Advanced Research in Pharmaceutical Sciences and Pharmacology Interventions 2 (2018).

8. Standard Unani treatment guidelines for common diseases, Volume-II, Central Council for Research in Unani Medicine, New Delhi (2016): 185-187.

\section{Assets from publication with us}

- Prompt Acknowledgement after receiving the article

- Thorough Double blinded peer review

- Rapid Publication

- Issue of Publication Certificate

- High visibility of your Published work

Website: https://www.actascientific.com/

Submit Article: https://www.actascientific.com/submission.php Email us: editor@actascientific.com

Contact us: +919182824667 